\title{
Social entrepreneurship innovation: A study from Mexico
}

\author{
María Teresa de la Garza Carranza, Eugenio Guzmán-Soria, \\ Jorge Armando López-Lemus, Ana Cristina Sierra Martínez
}

\begin{abstract}
A B S T R A C T
Objective: The objective of this research is to explore the personal and organizational factors that lead to innovation among social entrepreneurs in Mexico.

Research Design \& Methods: The study includes 81 social entrepreneurs from different regions of Mexico. A questionnaire was developed taking into account five factors: creativity, autonomy, tasks, and roles of the entrepreneur and the innovation of the process and product or service. We used the quantitative approach, with structural equations. The method used was partial least squares. The research model was tested and finally the relationship between variables were confirmed.
\end{abstract}

Findings: The relationship between the personal and organizational variables of the social entrepreneur on product or service innovation was verified. The social entrepreneur innovates to reach proposed goals. The mediation analysis was significative and provided new research patterns for future study.

Implications \& Recommendations: It is necessary to sensitise the different governmental and non-governmental sectors that promote social entrepreneurship in Mexico. Social entrepreneurship education could contribute to address the economic and labour shortage in Mexico. Social entrepreneurship could be an alternative way for contributing to the development of the economy and employment, particularly in emerging markets.

Contribution \& Value Added: This article highlights the personal and organizational factors of social entrepreneurs in Mexico that were previously studied. It contributes to the literature in the understanding of the innovation process that happens inside the social enterprise led by the business owner or manager.

\begin{tabular}{ll}
\hline Article type: & research article \\
Keywords: & social entrepreneurship; creativity; autonomy; innovation; partial \\
& least square; México \\
JEL codes: & L31, M14
\end{tabular}

Received: 17 June 2020 Revised: 21 September 2020 Accepted: 23 September 2020

\section{Suggested citation:}

De la Garza-Carranza, M.T., Guzmán-Soria, E. López-Lemus, J.A., \& Sierra-Martínez, A.C. (2020). Social Entrepreneurship Innovation: A study from México. Entrepreneurial Business and Economics Review, 8(4), 201-202. https://doi.org/10.15678/EBER.2020.080411 


\section{INTRODUCTION}

Social entrepreneurship (SE) in Mexico has been studied by different authors (Bojica, RuizJiménez, Ruiz-Nava, \& Fuentes-Fuentes, 2018; Villegas-Mateos \& Vázquez-Maguirre, 2020). These authors conclude that this type of organization is underdeveloped in Mexico, since there is no sustainable ecosystem that allows its development. They conclude that there are still legal and governmental aspects that exclude this type of organization from obtaining and managing resources. In answer to these issues, the Law of Social and Solidarity Economy was enacted in 2012, but it still has aspects that do not include a precise differentiation of SEs with other types of social or charitable organizations (Sandoval, 2019). Most studies conducted on Mexican SE focus on studies of rural organizations (Gómez-Carreto, Zarazúa-Escobar, Guillen-Cuevas, \& Castellanos-Albores, 2018; Villanueva, Jimenez, Garrido, \& Castro, 2012). This article contributes to explain from the viewpoint of activities carried out by entrepreneurs, and how the innovation process is performed in Mexican SE. In this way, the article contributes to a phenomenon that has not been addressed previously.

The objective of this research was to identify how entrepreneurial competencies at a personal level impact innovation in Mexican SEs. For this purpose, the article is divided into four parts. Firstly, a theoretical framework was developed in which the nature of social enterprises and the entrepreneur is addressed - taking into account their personal traits and organizational competencies - and the hypotheses are postulated. Subsequently, the study sample is described, along with descriptive statistics of items used. To test the hypotheses established in the model, the partial least squares technique was introduced with Smart-PLS 3. In the results section, we address the quality, reliability, and validity of the instruments used for the corroboration of hypotheses. Finally, the conclusions and recommendations are given regarding the skills and knowledge that must be reinforced so that social enterprises are sustainable and support social development in Mexico.

This work highlights the personal and organizational factors of the social entrepreneur in Mexico that had not been previously studied. It contributes to the literature in the understanding of the innovation process that happens inside the social enterprise led by the business owner or manager. Due to the severe crisis caused by the global pandemic, SE will be today a strategical sector for overcoming social lags, especially in emerging markets.

\section{LITERATURE REVIEW}

\section{Social Enterprises}

The attempt to conceptualise what a social enterprise is led researchers to divide it into two main approaches: the conceptualization that is taken from the European perspective and the one taken from the viewpoint of the United States of America (Defourny \& Nyssens, 2010). The conception of social enterprise in Europe has a long tradition, since it traces its origins to the social and economic reconstruction of the twentieth century, but it was developed after the Second World War as a way to cover the ravages of war. For example, in some European countries such as Germany, Belgium, and England there is strong support for the third sector by the government, but there are different conceptions in each country. In order to identify and define social enterprises, the project 'EMES' was 
created by the European Commission - an executive body of the European Union - that started in 1996 and ended in 2000. This acronym EMES stands for 'EMergence des Enterprises Sociales en Europe,' which integrated academics from different countries to carry out research on the subject (Davister, Defourny, \& Gregoire, 2004). The definition proposed by the EMES on social enterprises is the following: Social enterprises are private non-profit organizations that provide goods or services directly related to their explicit objective of benefiting the community. In general, they rely on a collective dynamic that involves various types of stakeholders in their governing bodies, place a high value on their autonomy, and take economic risks related to their activity (Davister et at., 2004).

From the North American viewpoint, a social company is not well defined (Diochon \& Anderson, 2009), since it bases on the entrepreneur, not the company (Vega \& Kidwell, 2007). However, after an in-depth review, Diochon and Anderson (2009, p. 11) define it as: 'identifying an opportunity to improve social welfare, then acquiring and using the necessary resources to do so.' This definition includes the generation of profits, but without deviating from its basic mission: the social good. That is, SE can be commercially viable as long as it meets its social purposes (Emerson \& Twersky, 1996). From a process viewpoint, Yujuico (2008) proposes that an SE involves innovation in the combination of resources of any kind to tackle pressing social problems. One of the organizations that have contributed in an influential way to the development of social entrepreneurs in the world is Ashoka. This non-profit organization was founded in 1980 by Bill Drayton, one of the main creators of the term 'social entrepreneur.' Ashoka currently promotes the development of organizations for the common good in 93 countries, including Mexico. Furthermore, Ashoka has created a global community that generates changes and innovations for the development of organizations that can transform and impact society. The main areas where Ashokasponsored organizations have developed are economic development, youth learning and development, the environment, education, health, human rights, and civic engagement (Sen, 2007).

\section{Social Entrepreneurship}

Many authors define the characteristic features of entrepreneurs, one of the most cited articles is the one by Lumpkin and Dess (1996) which defines entrepreneurial orientation as a set of attributes that the entrepreneur must have. These attributes include autonomy, risk-taking, proactivity, aggressiveness towards competitors, and innovativeness. However, SEs differ in their impact on the community from any other type of entrepreneur. Although there is no consensus about the definition of a SE (Germak \& Robinson, 2014), one of the commonly accepted definitions is that of Zahra, Gedajlovic, Neubaum, and Shulman (2009). These authors consider that SEs require considering the motivational attributes of the individuals or groups of individuals who take associated risks. Moreover, all the elements that lead to creating a new organization, but without forgetting that it must be for a social benefit. Therefore, they define the SE as 'the person who encompasses the activities and processes undertaken to discover, define and exploit opportunities in order to improve social wealth by creating new companies or managing existing organizations in an innovative way' (Zahra et al., 2009, p. 522).

In this sense, Forouharfar, Rowshan, and Salarzehi (2018) reviewed definitions of SE by more than 20 authors to conclude the main features that define this term are 1) social 
innovation that seeks to improve the conditions of those who are in a situation of vulnerability, 2) the social transformation of those involved in entrepreneurship, 3) the acknowledgement of chances that create social value, 4) a social mission, 5) initiatives not restricted to a single sector of society - as they can be for-profit or non-profit and may be in the public or private sector - and 6) creativity as the basis for the development and prosperity of entrepreneurship.

From a start-up viewpoint, three basic tasks must be carried out for a social enterprise to develop. 1) The definition of the opportunity to impact social and economic development in such a way that profits can be generated for those involved. 2) The start-up of an organization, for which the entrepreneur must have the necessary skills to operate a company. In this phase, a human resource base must be created to allow for the development of the organization's mission. 3) The creation of working capital that allows the organization to operate during start-up and development stages. Funding sources can be diverse and public funds can even be used (Perrini \& Vurro, 2006). According to the aforementioned authors, the ventures are generally developed in social areas for attending to different needs of e.g. children, women, youth.

Based on previous studies, for a SE to be successful, s/he must have autonomy to direct efforts in search of social benefit, creativity to look for opportunities in the environment, constantly seek innovation in the product or service and in the processes, and finally, s/he must seek self-efficiency in order to achieve the organization's social goals. Next, we will detail each of these variables and identify the hypotheses.

Entrepreneur autonomy. Social psychologists found great success using intention-toaction models such as that developed by Ajzen (1987). This model has been widely used in practical situations such as career preferences or product purchases. When a behaviour is difficult to observe, the person's intentions are critical in the process, and this can also be applied to entrepreneurial behaviour (Krueger, Reilly \& Carsrud, 2000). Autonomy then is the antecedent of entrepreneurial intention (Van Gelderen, 2010) and represents internal support for one's actions: it is the feeling that the actions belong to the person. Gibb (2002) states that more and more people are participating in the entrepreneurial movement as a result of various powerful trends in the society and the way people relate to governments, organizations, and others. These tendencies strongly favour self-sufficiency, and this is what an enterprise seeks, whether it has a social mission or not.

Autonomy is also a value significant for business entrepreneurs. Kirkeley (2016) investigated the role of values in entrepreneurial behaviour to find that the most important values among entrepreneurs are self-direction, ambition, creativity, and challenging the status quo. In the Mexican case, the main reason for starting a business is reaching financial independence, but also autonomy and personal development (Robichaud, Cachon, Taghzouti, Assaidi, \& Codina, 2019). This study will evaluate the entrepreneur autonomy skill that has not been evaluated in Mexican social entrepreneurs.

Creativity. Amabile (1996) defines one's creativity as the production of new and useful ideas in any area. Creativity is characteristic of all people, but not all of us transform that creativity into something tangible. A creative idea should bring utility to the organization to influence the way a business operates (Fillis, 2002). Creativity for entrepreneurs has significant challenges since, in most cases, they do not have enough capital, and it is difficult to materialise creative ideas in goods or services (Ward, 2004). In the 
case of social entrepreneurs, this creativity must recognise a need in the society so as to be able to generate better living conditions for those involved in entrepreneurship (Monllor \& Attaran, 2008). Therefore, we consider that there must be a relationship between the autonomy of the entrepreneur and creativity.

Creativity means not only alertness towards opportunities in the market, it also means the creation of new possibilities (Kirzner, 2009). There is a strong relationship between bricolage - the combining and reusing of resources - and creativity (An, Zhang, You, \& Guo, 2018). Creativity and autonomy are an alternative to resource constrains of the environment like the ones faced by SE. The impact of creativity in the output of SE has not been measured. Social innovation eventually links diverse factors, including the creativity of an entrepreneur. Thus, our first hypothesis is:

H1: There is a positive relationship between social entrepreneurs' autonomy and their creativity.

SEs' Innovation. Perrini and Vurro (2006) conceptualise the SE as the innovator who can contribute to social change, taking into account the classic process of entrepreneurship. Social innovation is developed when the patterns of social systems are changed and the innovation happens to fulfil a social need or market failure (Nicholls \& Murdock, 2012). These innovations can be of different types: social integration, social assistance, sustainability, financing, or educational. Therefore, social innovation is an effort to develop new paths that lead to creating conditions of well-being for those involved in entrepreneurship and technology to positively influence this effort (Caroli, Fracassi, Maiolini, \& Carnini-Pulino, 2018). According to Westley and Antadze (2010), a SE can be part of a social enterprise and simultaneously promote social innovation which seeks a permanent change in welfare conditions, such as the reduction of poverty, pollution, school dropout, or violence.

The SE offers alternative and innovative ways of tackling social value and wealth creation (Chell, Nicolopoulou, \& Karataş-Özkan, 2010). Scillitoe, Poonamellee, and Joy (2018) propose a model for sociotechnological innovation. They posit that the innovation will depend on factors such as organization tenures, leader's enthusiasm for innovation, market orientation (profit, non-profit), and legal aspects. As organizations develop new ways of impacting the social sector, entrepreneurs develop competencies related to innovation. As for example, when a small rural ecotourism business has to develop competencies to do ecommerce This strategic development could create new clients, but it also demands the improvement of service.

For the purpose of this study, we consider two types of innovation: product (or service) and innovation process. Innovation in the product or service is related to the market or the final consumers of the venture. Improvement in the innovation process refers to the internal way of how the good or service is produced. There is a growing trend in social innovation to attack market niches that can contribute to social development (Witkamp, Raven, \& Royakkers, 2011). Also, innovation help organizations to overcome turbulent environments of economy (Jiménez-Jiménez \& Sanz-Valle, 2011). The objective is to develop innovative products or services that contribute to sustainable development. Therefore, we postulate the following hypotheses:

H2: There is a positive relationship between social entrepreneurs' creativity and the innovation process of the social enterprise. 
H3: There is a positive relationship between social entrepreneurs' autonomy and the innovation process of the social enterprise.

H4: There is a positive relationship between innovation process and product (or service) innovation of the social enterprise.

Entrepreneur tasks and roles. The creation of a company is a decision of the SE and is subject to a complex process in which intervene various factors. Kazanjian (1998) identified various activities that new organizations must consider to innovate: organizational systems, sales/marketing, human resources, strategic positioning, production, and external relations. These activities are known as entrepreneurship efficiency and were studied by various authors (Hsu, Wiklund, \& Cotton, 2017; Mauer, Neergaard, \& Linstad, 2017). Efficiency in entrepreneurship roles is generally accepted to predict the ability of the entrepreneur to generate new companies (Chen, Greene, \& Crick, 1998; Douglas \& Fitzsimmons, 2012). The high concept of efficiency in entrepreneurs implies that they can be alert to recognise opportunities in market imbalances and to evaluate opportunities in a timely manner (Tang, 2008).

Entrepreneurs need abilities and skills to identify and create business opportunities, but also to promote social innovation. The self-efficiency capabilities would help the entrepreneur to manage and take action in diverse situations (Valencia-Arias \& Marulada-Valencia, 2019). Chen and Zhou (2017) found that entrepreneurial self-efficiency positively relates to innovation thanks to entrepreneurs' motivation to be efficient at a personal and organizational level and to achieve goals. But there are studies (Shepherd, Patzelt, \& Baron, 2013; Cooper, Peake, \& Watson, 2016) that confirmed the relationship between self-regulation, personal characteristics, and the entrepreneur task and roles. However, this relationship was never proved in the Latin-American context. Therefore, our last hypotheses are:

H5: There is a positive relationship between the tasks and roles a social entrepreneur performs and the innovation process of the social enterprise.

H6: There is a positive relationship between autonomy and the tasks and roles that the social entrepreneur shows.

The research model is shown in Figure 1.

Structural equation modelling (SEM) was used to test our research model. SEM is a statistical technique that helps to understand representations involving several variables in a model that goes beyond multiple linear regressions. The objective of statistical modelling through SEM is to answer complex questions regarding latent variables (VargasChanes, 2019). SEM is a variant of traditional multivariate models, in which a structural equation model is a system of multiple regressions that are interconnected by paths, in which an independent variable could be connected with multiple dependent or mediating variables (Fox, 2002). The objective of SEM is to represent causal relationships between two or more latent variables at the same time. Russell, Kahn, Spoth, and Altmaier (1998) propose that SEM is useful to evaluate the mediation effects of an intervention programs in the current study, in which we have one independent variable (creativity), three mediating variables (autonomy, innovation process, and task and roles), and one dependent variable (the innovation of product or service).

There are currently two types of SEM generally used. One is based on covariance to confirm or reject theories, while the other one is based on partial least squares (PLS) to develop theories in an exploratory study. The latter technique has the advantage that it 
can handle small sample sizes and the distribution of the data does not need to be normal, since it is a non-parametric technique (Hair, Hult, Ringle, \& Sarstedt, 2016). The software used for the analysis was Smart-PLS 3.

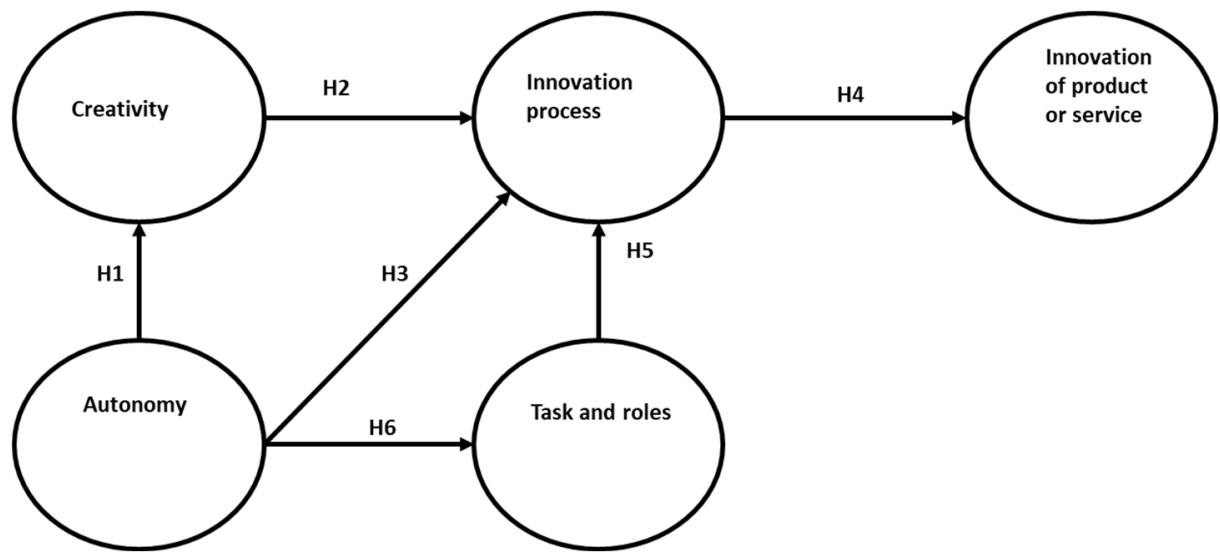

Figure 1. Research model Source: own elaboration.

\section{RESEARCH METHODOLOGY}

Structural equation modelling (SEM) was used to test our research model. SEM is a statistical technique that helps to understand representations involving several variables in a model that goes beyond multiple linear regressions. The objective of statistical modelling through SEM is to answer complex questions regarding latent variables (Vargas-Chanes, 2019). SEM is a variant of traditional multivariate models, in which a structural equation model is a system of multiple regressions that are interconnected by paths, in which an independent variable could be connected with multiple dependent or mediating variables (Fox, 2002). The objective of SEM is to represent causal relationships between two or more latent variables at the same time. Russell, Kahn, Spoth, and Altmaier (1998) propose that SEM is useful to evaluate the mediation effects of an intervention programs in the current study, in which we have one independent variable (creativity), three mediating variables (autonomy, innovation process, and task and roles), and one dependent variable (the innovation of product or service).

There are currently two types of SEM generally used. One is based on covariance to confirm or reject theories, while the other one is based on partial least squares (PLS) to develop theories in an exploratory study. The latter technique has the advantage that it can handle small sample sizes and the distribution of the data does not need to be normal, since it is a non-parametric technique (Hair, Hult, Ringle, \& Sarstedt, 2016). The software used for the analysis was Smart-PLS 3.

\section{Sample and Data Collection}

The sample was obtained for convenience because there is no registered list of SEs in Mexico. The respondents were located through their social networks, following the type of social impact they had in the community. Once located by Facebook, email, or phone, 81 
responses were obtained from SEs from the states of Guanajuato, Jalisco, Oaxaca, and Querétaro. Like most of Mexico, these states continue to struggle with development, especially in rural communities. In our sample, $57 \%$ of the respondents were women and $43 \%$ men. Among them, $41 \%$ were between 24 and 30 years old, $57 \%$ were between 31 and 40 years old, and $2 \%$ were over 40 . Four per cent had basic education, $23 \%$ - a high school degree, $2 \%$ - a technical degree, $58 \%$ - a bachelor's degree, and $13 \%$ - a master's degree. Most of the organizations were young, because $81 \%$ were between one to three years old, a small amount (10\%) was less than one year old, and only $9 \%$ were more than four years old. In the studied population, $26 \%$ of companies had less than three employees, $70 \%$ - from four to 10 employees, and $4 \%$ had more than 10 employees. In the vast majority of cases, companies were of the service type (97\%), although a minority was in the manufacturing industry (3\%). Regarding the experience of the entrepreneurs, $5 \%$ were recently new, $90 \%$ had less than five years of experience, and $5 \%$ had more than five years of experience such organizations. Among the interviewed, $56 \%$ stated that they were owners of the companies, and $44 \%$ - their main administrators.

\section{Development of Instruments}

As described above, the instrument or questionnaire has five variables. The measurement instrument was originally developed by Ahlin, Drnovšek, and Hisrich (2014). It was taken as the basis for the questionnaire of creativity, innovation process, product or service innovation, and tasks and roles. These authors based their questionnaire on Hills, Lumpkin, and Singh (1997) to develop the creativity items. Regarding the innovation process, the scales were developed by Jiménez-Jiménez and Sanz-Valle (2011), while for the innovation of the product or service we used the questionnaire by Yang, Wang, and Cheng (2009). We adopted the tasks and roles questionnaire from Chen et al. (1998). Finally, the autonomy questionnaire was taken from the one developed by Engle et al. (2008). Table 1 shows the items used in each of the questionnaires cited, along with their mean and variance of the 81 collected cases. In all cases, a Likert scale from 1 to 7 was used, in which 1 meant totally disagree and 7 totally agree. Regarding the sample size, the generally accepted criterion is to look for the significance level of $5 \%$, the power of the test of $80 \%$, and the minimum value of $R^{2}$ of 0.25 (Wong, 2013). Thus, for our study, the suggested sample size is 80 . Hence, the criteria are meet. Table 1 shows the descriptive statistics of the data.

As shown in Table 1, most of the items are in the range of 6 , which means that a general agreement is shown by the entrepreneurs. The higher standard deviations were obtained in items C2, IN3, and T3, so these activities show higher variability.

\section{RESULTS AND DISCUSSION}

\section{Measurement Model}

To evaluate the reliability and validity of the measurement model, the convergent validity and internal consistency of the model was collected in Table 2. For convergent validity, outer weights were estimated by a partial multiple regression for the latent variable using the PLS algorithm: 'High outer loadings on a construct indicate that the associated indicators have much in common' (Sarstedt, Ringle, Smith, Reams, \& Hair, 2014, p. 102). Generally, an outer loading should be higher than 0.70 . The square of a standardised indi- 
Table 1. Statistics of the items used

\begin{tabular}{|c|c|c|}
\hline Item, author & Mean & Standard Deviation \\
\hline \multicolumn{3}{|l|}{ Creativity (C) Hills et al. (1997) } \\
\hline C1. I am a very creative person. & 6.41 & 0.932 \\
\hline C2. I take a few minutes a day or a week to get creative. & 5.77 & 1.325 \\
\hline C3. I regulate my time. & 6.41 & 0.787 \\
\hline C4. I am very sensitive to problems that others do not see. & 6.70 & 0.601 \\
\hline \multicolumn{3}{|l|}{ Autonomy (A) Engle et al. (2008) } \\
\hline A1. I have many ideas. & 6.42 & 0.739 \\
\hline A2. I can express my own personality and creativity. & 6.51 & 0.654 \\
\hline A3. I am in charge and in control of my work. & 6.42 & 0.722 \\
\hline \multicolumn{3}{|l|}{ Innovation of product or service (IN) Yang et al. (2009) } \\
\hline $\begin{array}{l}\text { IN1. The number of firm's new products that are first-to-market (or } \\
\text { early market entrants). }\end{array}$ & 6.07 & 0.959 \\
\hline $\begin{array}{l}\text { IN2. The number of new products and/or services a firm has intro- } \\
\text { duced to the market }\end{array}$ & 6.28 & 0.794 \\
\hline IN3. The speed of firm's new product and/or services development. & 5.78 & 1.107 \\
\hline \multicolumn{3}{|l|}{ Innovation Process (I) Jiménez-Jiménez \& Sanz-Valle (2011) } \\
\hline I1 The number of changes introduced in processes. & 6.32 & 0.819 \\
\hline 12. Pioneer disposition to introduce new processes. & 6.12 & 0.900 \\
\hline $\begin{array}{l}\text { 13. Clever responses to new processes introduced by other compa- } \\
\text { nies in the same sector. }\end{array}$ & 5.99 & 0.994 \\
\hline \multicolumn{3}{|l|}{ Task and roles $(T)$ Chen et al. (1998) } \\
\hline T1. I can set and achieve profit-based goals. & 6.32 & 0.772 \\
\hline T2 I can control costs. & 6.42 & 0.687 \\
\hline T3. I can define the roles of the organization. & 6.21 & 1.021 \\
\hline T4. I can define responsibilities. & 6.32 & 0.933 \\
\hline T5. I can develop new ideas. & 6.35 & 0.824 \\
\hline T6. I can develop new products and services. & 6.15 & 0.989 \\
\hline T7. I can establish a company. & 6.35 & 0.938 \\
\hline
\end{tabular}

Source: own study.

cator of an outer loading represents how much of the discrepancy in that element is explained by the latent variable. Finally, Table 2 shows the extracted average variance (AVE). For the internal consistency of the questionnaire used, it presents two indicators: the widely used Cronbach's alpha and composite reliability, which presents fewer drawbacks than Cronbach's Alpha (Bagozzi \& Yi, 1988).

\section{Model Evaluation}

As a first step, we calculated the Pearson's correlations among studied variables. This is shown in Table 3, all the correlations are statistically highly significant, because they have a $p$ value of less than 0.01 . In order to obtain the results for the path model, we used a bootstrapping resample method for exploratory analysis as recommended. The results of the path model appear in Figure 2. According to Hair Jr et al. (2016), no effective measures have yet been developed that can assess the adequacy of the model. However, general measurements such as the standardized root mean square residual (SRMR) have been pro- 
Table 2. Parameters of the measurement model

\begin{tabular}{|c|c|c|c|c|c|c|}
\hline \multirow[b]{2}{*}{$\begin{array}{l}\text { Latent vari- } \\
\text { able }\end{array}$} & \multirow[b]{2}{*}{$\begin{array}{l}\text { Indica- } \\
\text { tors }\end{array}$} & \multicolumn{3}{|c|}{ Convergent validity } & \multicolumn{2}{|c|}{ Internal consistency reliability } \\
\hline & & $\begin{array}{c}\text { Indicator } \\
\text { Loadings } \\
>0.70\end{array}$ & $\begin{array}{l}\text { Indicator reliabil- } \\
\text { ity (loading }{ }^{2} \text { ) } \\
>0.50\end{array}$ & $\begin{array}{c}\text { AVE } \\
>0.50\end{array}$ & $\begin{array}{c}\text { Composite reli- } \\
\text { ability } \\
>0.70\end{array}$ & $\begin{array}{l}\text { Cronbach's } \\
\text { Alpha } \\
>0.60\end{array}$ \\
\hline \multirow{4}{*}{ Creativity } & C1 & 0.958 & 0.917 & \multirow{4}{*}{0.856} & \multirow{4}{*}{0.960} & \multirow{4}{*}{0.943} \\
\hline & $\mathrm{C} 2$ & 0.966 & 0.933 & & & \\
\hline & $\mathrm{C3}$ & 0.905 & 0.819 & & & \\
\hline & $\mathrm{C} 4$ & 0.858 & 0.736 & & & \\
\hline \multirow{3}{*}{ Autonomy } & A1 & 0.949 & 0.900 & \multirow{3}{*}{0.871} & \multirow{3}{*}{0.953} & \multirow{3}{*}{0.926} \\
\hline & $\mathrm{A} 2$ & 0.919 & 0.844 & & & \\
\hline & A3 & 0.931 & 0.866 & & & \\
\hline \multirow{3}{*}{$\begin{array}{l}\text { Innovation } \\
\text { process }\end{array}$} & 11 & 0.842 & 0.708 & \multirow{3}{*}{0.823} & \multirow{3}{*}{0.933} & \multirow{3}{*}{0.891} \\
\hline & 12 & 0.955 & 0.912 & & & \\
\hline & 13 & 0.921 & 0.848 & & & \\
\hline \multirow{7}{*}{$\begin{array}{l}\text { Tasks and } \\
\text { roles }\end{array}$} & T1 & 0.907 & 0.822 & \multirow{7}{*}{0.840} & \multirow{7}{*}{0.974} & \multirow{7}{*}{0.968} \\
\hline & $\mathrm{T} 2$ & 0.876 & 0.767 & & & \\
\hline & T3 & 0.914 & 0.835 & & & \\
\hline & T4 & 0.947 & 0.896 & & & \\
\hline & T5 & 0.916 & 0.839 & & & \\
\hline & T6 & 0.904 & 0.817 & & & \\
\hline & T7 & 0.951 & 0.904 & & & \\
\hline \multirow{3}{*}{$\begin{array}{l}\text { Innovation } \\
\text { of product } \\
\text { or service }\end{array}$} & IN1 & 0.913 & 0.833 & \multirow{3}{*}{0.777} & \multirow{3}{*}{0.913} & \multirow{3}{*}{0.856} \\
\hline & IN2 & 0.824 & 0.678 & & & \\
\hline & IN3 & 0.905 & 0.819 & & & \\
\hline
\end{tabular}

Source: own study.

posed. To obtain the SRMR, two matrices are developed: sample covariance and predicted covariance. The difference of both is a measurement of statistical accuracy. Therefore, this indicator allows for evaluating the average magnitude of discrepancies between observed and expected correlations as an absolute measure of the fit criterion (model). A value less than 0.10 or 0.08 (Hu \& Bentler, 1998) is considered a good fit. Henseler et al. (2014) present the SRMR as a degree of goodness of fit for PLS-SEM that can be used to avoid erroneous description of the model. In this case, the value of 0.086 was obtained, which complies with the established parameter. A generally accepted parameter to assess the degree of predictability of the model is the multiple determination coefficient or $\mathrm{R}^{2}$, which explains the proportion of the total variance in the variable explained by the regression. In this case, we can see that in the predictor or dependent variables, all the values of $\mathrm{R}^{2}$ are greater than 0.60 (Creativity, Innovation process, Tasks and Roles, and Innovation of the product or service).

As we obtained acceptable results for the reliability and validity criteria of the constructs or latent variables - but also for the indicators of the model - we can corroborate our hypotheses, because all paths are significant. As Hair, Sarstedt, Hopkins, and Kuppelwieser (2014) state: 'path coefficient values are standardised on a range from 1 to -1 , with coefficients closer to 1 representing strong positive relationships and coefficients closer to -1 indicating strong negative relationships' (p. 114). This parameter is useful in testing our hypothesis. 
Table 3. Pearson correlations of studied variables

\begin{tabular}{|l|l|l|l|l|l|}
\hline Construct & Creativity (C) & Autonomy (A) & $\begin{array}{l}\text { Innovation prod- } \\
\text { uct or service (IN) }\end{array}$ & $\begin{array}{l}\text { Innovation } \\
\text { process (I) }\end{array}$ & $\begin{array}{c}\text { Tasks and } \\
\text { Roles (T) }\end{array}$ \\
\hline $\mathrm{C}$ & 1 & & & & \\
\hline $\mathrm{A}$ & $0.676^{* *}$ & 1 & & & \\
\hline $\mathrm{IN}$ & $0.751^{* *}$ & $0.772^{* *}$ & 1 & & \\
\hline $\mathrm{I}$ & $0.809^{* *}$ & $0.808^{* *}$ & $0.795^{* *}$ & 1 & \\
\hline $\mathrm{T}$ & $0.708^{* *}$ & $0.789^{* *}$ & $0.660^{* *}$ & $0.815^{* *}$ & 1 \\
\hline
\end{tabular}

Source: own elaboration.

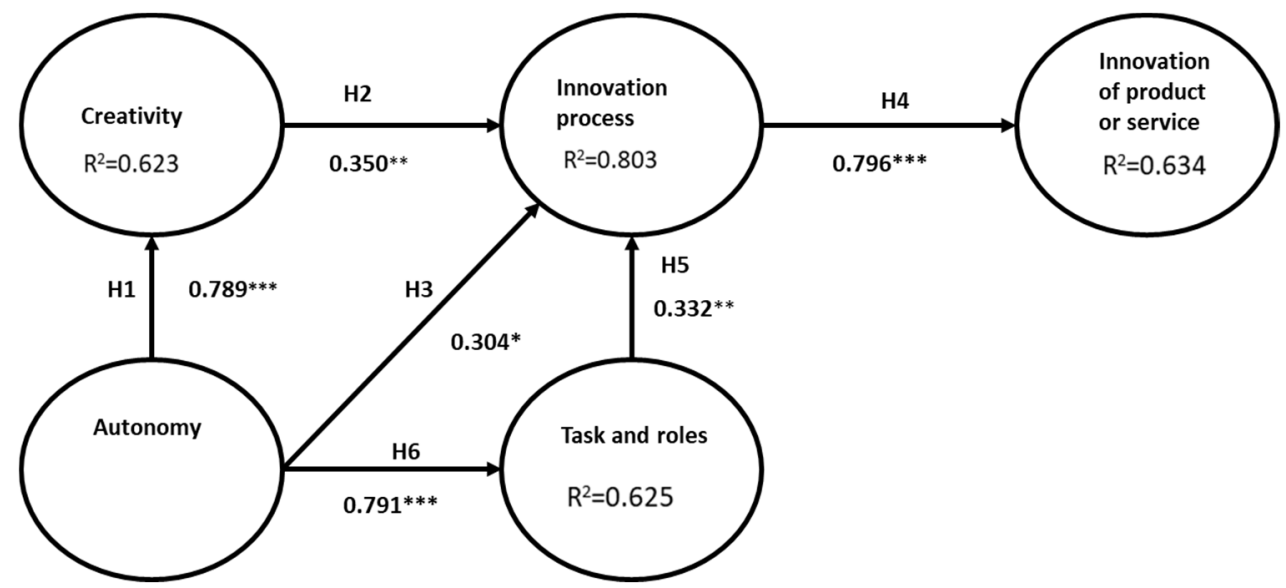

Figure 2. Results of the path model

Notes for the model: ${ }^{* * *} p<0.001$ (very high), ${ }^{* *} p<0.01$ (high), ${ }^{*} p<0.05$ (moderate). The path coefficients are from the original sample. $\mathrm{R} 2$ is the multiple determination coefficient. Source: own elaboration.

The structural model evaluations from the outcomes of the PLS algorithm confirm all of our hypotheses. In this sense, two parameters were considered to accept or reject our hypothesis: 1 ) the Pearson correlation between variables obtained by the sample (Table 3), and 2 ) the path coefficient and test estimates by the bootstrapping method and their significance levels. Benitez, Henseler, Castillo, and Schuberth (2020, p. 12) state that, '[s]tandardized regression coefficients are interpreted as change in standard deviations of the dependent variable if an independent variable is increased by one standard deviation while all other independent variables in the equation remain constant.' Thus, we present four parameters in assessing the relationships between the latent variables: a) Pearson correlation $(\rho)$, b) standardized regression coefficient from the sample $(\beta), c)$ Student's t-test for the parameter from the bootstrapping method, and d) the $\alpha$ of the significance for the test. For $\mathrm{H} 1$, the relationship between the variables autonomy and creativity is accepted $(\rho=0.676, \beta=0.789, t=15.4$, and $\alpha=0.000)$. This implies a strong relationship between these two personal attributes of an entrepreneur. Our findings are consistent with Smith, Bell, and Watts (2014) who found that SEs exhibit better relations in creativity levels, daring, and need for self-sufficiency than traditional 
entrepreneurs. Hypothesis 2 assesses the relationship between creativity and innovation process $(\rho=0.809, \beta=0.350, t=2.89$, and $\alpha=0.004)$. This hypothesis is also confirmed. Vuong and Napier (2014) propose that creativity should encourage the innovation process in the organization, especially in entrepreneurship. Hypothesis 3 foregrounds the relationship between the autonomy of an entrepreneur and the innovation process $(\rho=0.808, \beta=0.304, t=2.10$, and $\alpha=0.033)$. In this case, the hypothesis is accepted, but the significance of the test is moderate. These results confirm the study by Baron and Tang (2011) performed in the USA, who nevertheless identify the dynamism of the environment as the mediation variable. In this sense, future studies in turbulent times could analyse the economic environment as part of the entrepreneurship process. Hypothesis 4 established a positive relationship between the variables of innovation process and the innovation of product or service. Hypothesis 4 is also accepted $(\rho=0.795, \beta=0.796, t=12.07$, and $\alpha=0.000$ ), which means that is a strong relationship between these two variables. Aksoy (2017) found a strong positive relationship between product novelty and market results in small businesses. Hypothesis 5 is confirmed $(\rho=0.815$, $\beta=0.332, t=2.58$, and $\alpha=0.010$ ), as the task and roles that an SE performs are activities needed to promote the innovation process. Ng and Lucianetti (2016) found that when a person rises in self-efficacy beliefs, it promotes idea generation, diffusion, and implementation over time. Finally, hypothesis 6 stated that the relationship between autonomy and entrepreneur's roles and tasks is significant $(\rho=0.789, \beta=0.791, t=15.64$, and $\alpha=0.000)$, which is also confirmed. Shir, Nikolaev, and Wincent (2019) found a strong relationship between autonomy and entrepreneurship. The freedom of behaviour that an entrepreneur has in operating a company is one of the reasons why a person becomes an entrepreneur.

Additionally, we calculated indirect effects. These paths can contribute to the exploration of new possibilities in research of SEs personality and skills. The variance accounted for (VAF) determined the size of the indirect effect in relation to the total effect. The objective was to 'determinate the extent to which the variance of the dependent variable is directly explained by the independent variable and how much of the target construct's variance is explained by the indirect relationship via the mediator variable' (Hair, Hult, Ringle, \& Sars, 2014, p. 225). We employed the bootstrapping method to assess this effect and obtain VAF indexes for total indirect effects. The confidence intervals and the thatistics are shown in table 4.

Table 4. Mediation effects analysis

\begin{tabular}{|l|l|l|l|l|c|}
\hline \multicolumn{1}{|c|}{ Path } & \multicolumn{1}{|c|}{ VAF } & Lower bound (2.5\%) & Upper bound (97.5\%) & \multicolumn{1}{c|}{ t } & p \\
\hline A-I & 0.669 & 0.533 & 0.786 & 10.22 & 0.000 \\
\hline A-IN & 0.549 & 0.314 & 0.820 & 4.16 & 0.000 \\
\hline C-I & 0.286 & 0.117 & 0.489 & 2.98 & 0.003 \\
\hline T-IN & 0.262 & 0.103 & 0.261 & 2.54 & 0.012 \\
\hline
\end{tabular}

Note: A (Autonomy), IN (Innovation product or service), C (Creativity), I (innovation process), T (Task \& roles). Source: own study.

The mediation results showed that all paths are significant because in all cases $p<0.01$, which means that all studied variables are necessary for the innovation of products or services. Once the entrepreneur has an innovation in the market, the social innovation begins due to the actions done by the entrepreneur. 


\section{CONCLUSIONS}

The importance of social entrepreneurship goes farther than simply a charity organization. Santos (2012) states that, 'SE is an innovation process in the economy that can happen in different institutional contexts, is based on value creation, and operates by its own rules and logic. It is an approach that seems well suited to address some of the most pressing problems in modern society and improve capitalism' (p. 350). The impact of social enterprises in economy is difficult to measure in this moment because the category is not well defined in an economic classification, but as Harding (2004) proposes, this kind of organizations could be the basis of a new economy, especially in turbulent times.

The aim of this study is to investigate the personal and skills characteristics of SEs. Regarding personal characteristics, our study proposes that there is a relationship between autonomy and creativity of the entrepreneur. Hypothesis 1 is accepted due to the strong relationship between the variables. Authors such as Perry-Smith and Mannucci (2017) and Bacq, Ofstein, Kickul, and Gundry (2015) support this idea. Moreover, in an analysis carried out on social and non-social entrepreneurs, Smith et al. (2014) found that the need for autonomy is greater among the former. Hypotheses two and three relate to autonomy and creativity in product innovation. Both hypotheses are accepted because they present positive significant statistical parameters. In this sense, Orth and Volmer (2017) establish a relationship between creativity, autonomy, and innovative behaviour based on the personal characteristics of a worker. At present, no literature on this relationship was found for SEs. This work presents a theoretical contribution in this regard.

In relation to the skills presented by the SE, hypothesis 4 establishes a positive relationship between innovation in a process and innovation in a product or service. This relationship is significant and, therefore, hypothesis 4 is accepted. In this sense, Lumpkin et al. (2013) identify that social companies are looking for breaks in the market to correct difficulties in the environment, thus providing a solution to various problems that currently worry the society, e.g. poverty, education, or health. Moreover, SEs present opportunities to challenge and develop new capabilities and contribute to national systems of innovation, especially in emerging markets (Rao-Nicholson, Vorley, \& Khan, 2017).

Hypothesis five refers to tasks and roles and the innovation that the social innovator must carry out in the process, which was studied by Chen et al. (1998) on diverse entrepreneurs. In relation to the management of tasks and roles, creativity, and innovation Ahlin et al. (2014) establish a positive relationship between these three factors. Finally, hypothesis six refers to the tasks and roles and autonomy of the SE. This last relationship is accepted because it presents a positive and significant statistical relationship. Cavazos-Arroyo, PuenteDíaz, and Agarwal (2017) establish the personal characteristics of an SE with the tasks and roles that the entrepreneur must develop. Their study was conducted in Mexico among potential aspiring SEs in the state of Puebla. In general, our results agree with the findings of De la Garza-Carranza, Zavala-Berbena, López-Lemus, and López-de-Alba (2019) who show that the skill to manage an SE business is important to avoid failure.

An SE strives to maintain the results of the organization while seeking a social benefit for the community, which could be especially difficult in a restricted economy. There are success stories in Mexico that show that SEs can create organizations (Wulleman \& Hudon, 2016). In the studied cases, most organizations are small and of the 'social bricoleur' type 
(Zahra et al., 2009). A bricoleur SE is one who uses any type of resources to conduct the task for social benefit. These entrepreneurs make a significant effort to correct the social imbalances in their environment.

Our analyses leads us to conclude that the SE needs certain skills and personal traits to perform their work. This paper emphasises, that SE are important for the construction of feasible development strategies, for those suffer conditions of inequality in the society. Particularly in the Mexican case, there are many areas of opportunity for the creation of social innovation, since currently $42 \%$ of the population lives in poverty and $7.4 \%$ in extreme poverty (CONEVAL, 2018). Furthermore, there are important challenges in education, health, food, and housing. These problems that afflict a large number of Mexicans must be part of government strategies, but also of civil society, which is willing to commit itself in an organised way through social ventures. Our research results must be carefully observed, and they should influence organizations that help to develop social enterprises such as universities, local and federal government, and other ventures that promote a social change.

As the new economic crisis rises from the COVID-19 pandemic, many governments in emerging countries are facing social challenges to combat hunger and poverty. According to the International Labor Organization (ILO, 2020), the impact in Mexican society in terms of job loses is significant. This economic crisis is especially hitting women and young people. The most vulnerable sectors are manufacturing, hospitality business, and construction.

One of the strategies that the Mexican government can implement is to develop incentives for developing SEs. Mexico has a lot of resources in terms of culture, crafts, agriculture, and nature. Consequently, the idea of developing centres for the development of SEs - particularly in vulnerable communities - could create a social impact and mobility for those in vulnerable situation. To do this, the Ministry of Education may promote centres of SE development in its university network. For example, Tecnológico Nacional de México has around 250 campuses in all regions of Mexico. Thus, the results of this study could impact the development of abilities and characteristics that the SE need to develop a new venture.

This study presents limitations regarding the sample size due to the lack of a reliable list of SEs, while companies of this type generally have a local action where they market their products or services. Future studies should consider a larger sample size differentiated in organizations that have been operating for a longer time in order for the latter to relate to experience and social impact. The social impact of SEs was not measured in this study due to technical difficulties. Firstly, most SEs considered in the sample are young, and the social impact is directly related to the nature of the business, so it could be questionable after measurement. Secondly, there is no consensus on how to measure the social effect of SEs, because this concept is constructed of diverse aspects: economic, educational, stakeholders, and personal impacts to entrepreneurs and communities (Caroli et al., 2018). In this sense, the topic could be interesting for new research initiatives.

As our results suggest, the education of community leaders and university students in SE is an activity that should be considered by policymakers so as to increase the number of organizations devoted to social change. Thus, the development of strategies to include these topics in business courses could be a contribution of educational researchers into SE creation. In this sense, there is an opportunity for Mexican educational managers in developing SE curricula (Kickul, Gundry, Mitra, \& Berçot, 2018). 
As for proposals of future research related to entrepreneurs, we suggest two important aspects of SE. Firstly, more skills should be investigated regarding the planning capacity and how this activity is developed in actions for increasing innovation and achieving a social change. In this sense, there is an important lack in the literature in how innovation contributes to social change and how this concept could be measured. Secondly, it could be interesting to explore the interaction of factors that create synergies to influence the performance of entrepreneurs for achieving social goals.

The literature about SEs is under development especially in emerging economies. Moreover, the resources and legal aspects of SEs are insufficiently developed in Mexico, which offers opportunities for practitioners and researchers. SEs contributions to the economy and employment should be considered an emerging topic in the business literature, especially in times of crisis like the one we are currently experiencing.

\section{REFERENCES}

Ahlin, B., Drnovšek, M., \& Hisrich, R.D. (2014). Entrepreneurs' creativity and firm innovation: the moderating role of entrepreneurial self-efficacy. Small Business Economics, 43(1), 101-117. https://doi.org/10.1007/s11187-013-9531-7

Ajzen, I. (1987). Attitudes, traits, and actions: Dispositional prediction of behavior in social psychology. Advances in Experimental Social Psychology, 20, 1-63. https://doi.org/10.1016/S00652601(08)60411-6

Aksoy, H. (2017). How do innovation culture, marketing innovation and product innovation affect the market performance of small and medium-sized enterprises (SMEs). Technology in Society, 51(4), 133-141. https://doi.org/10.1016/j.techsoc.2017.08.005

Amabile, T.M. (1996). Creativity and Innovation in Organizations. Harvard Business School Background Note (pp. 396-239).

An, W., Zhang, J., You, C., \& Guo, Z. (2018). Entrepreneur's creativity and firm-level innovation performance: bricolage as a mediator. Technology Analysis \& Strategic Management, 30(7), 838851. https://doi.org/10.1080/09537325.2017.1383979

Bacq, S., Ofstein, L.F., Kickul, J.R., \& Gundry, L.K. (2015). Bricolage in social entrepreneurship: How creative resource mobilization fosters greater social impact. The International Journal of Entrepreneurship and Innovation, 16(4), 283-289. https://doi.org/10.5367\%2Fijei.2015.0198

Bagozzi, R.P., \& Yi, Y. (1988). On the evaluation of structural equation models. J. Acad. Mark. Sci. 16, 74-94. https://doi.org/10.1007/BF02723327

Baron, R.A., \& Tang, J. (2011). The role of entrepreneurs in firm-level innovation: Joint effects of positive affect, creativity, and environmental dynamism. Journal of Business Venturing, 26(1), 49-60. https://doi.org/10.1016/j.jbusvent.2009.06.002

Benitez, J., Henseler, J., Castillo, A., \& Schuberth, F. (2020). How to perform and report an impactful analysis using partial least squares: Guidelines for confirmatory and explanatory IS research. Information \& Management, 57(2), 103168. https://doi.org/10.1016/j.im.2019.05.003

Bojica, A.M., Ruiz Jiménez, J.M., Ruiz Nava, J.A., \& Fuentes-Fuentes, M.M. (2018). Bricolage and growth in social entrepreneurship organisations. Entrepreneurship \& Regional Development, 30(3-4), 362-389. https://doi.org/10.1080/08985626.2017.1413768

Cavazos-Arroyo, J., Puente-Díaz, R., \& Agarwal, N. (2017). An examination of certain antecedents of social entrepreneurial intentions among Mexico residents. Revista Brasileira de Gestão de Negócios-RBGN, 19(64), 180-199. https://doi.org/10.7819/rbgn.v19i64.3129 
Caroli, M.G., Fracassi, E., Maiolini, R., \& Carnini-Pulino, S. (2018). Exploring social innovation components and attributes: a taxonomy proposal. J. Soc. Entrep. 9, 94-109. https://doi.org/10.1080/19420676.2018.1448296

Chell, E., Nicolopoulou, K., \& Karataş-Özkan, M. (2010). Social entrepreneurship and enterprise: International and innovation perspectives. Entrepreneurship and Social Development, 22(6), 485493. https://doi.org/10.1080/08985626.2010.488396

Chen, C.C., Greene, P.G., \& Crick, A. (1998). Does entrepreneurial self-efficacy distinguish entrepreneurs from managers?. Journal of Business Venturing, 13(4), 295-316. https://doi.org/10.1016/S0883-9026(97)00029-3

Chen, Y., \& Zhou, X. (2017). Entrepreneurial self-efficacy and firms' innovation behavior: The negative mediating role of social capital. Social Behavior and Personality: an international journal, 45(9), 1553-1562. https://doi.org/10.2224/sbp.6734

CONEVAL. (2018). Medición de Pobreza. Retrieved from https://www.coneval.org.mx/Medicion/ PublishingImages/Pobreza_2018/Serie_2008-2018.jpg on April 30, 2020.

Cooper, D., Peake, W., \& Watson, W. (2016). Seizing Opportunities: The Moderating Role of Managerial Characteristics on the Relationship between Opportunity-Seeking and Innovation Efficacy in Small Businesses. Journal of Small Business Management, 54(4), 1038-1058. https://doi.org/10.1111/jsbm.12228

Davister, C., Defourny, J., \& Grégoire, O. (2004). Work integration social enterprises in the European Union: an overview of existing models. Revue Internationale de l'Économie Sociale: Recma, 293, 24-50.

Defourny, J., \& Nyssens, M. (2010). Conceptions of social enterprise and social entrepreneurship in Europe and the United States: Convergences and divergences. J. Soc. Entrep, 1, 32-53. https://doi.org/10.1080/19420670903442053

De la Garza Carranza, M.T., Zavala Berbena, M.A., López-Lemus, J.A., \& López de Alba, P.L. (2019). Inventario de las causas del fracaso en emprendedores sociales en México (CAFES-M). Revista Perspectivas, (43), 107-134.

Diochon, M., \& Anderson, A.R. (2009). Social enterprise and effectiveness: a process typology. Soc. Enterp. J., 5(1), 7-29. https://doi.org/10.1108/17508610910956381

Douglas, E., \& Fitzsimmons, J. (2012). Intrapreneurial intentions versus entrepreneurial intentions: Distinct constructs with different antecedents. Small Business Economics, 41(1), 115-132. https://doi.org/https://doi.org/10.1007/s11187-012-9419-y

Emerson, J., \& Twersky, F. (1996). New social entrepreneurs: The success, challenge and lessons of non-profit enterprise creation. The Homeless Economic Fund, the Roberts Foundation.

Engle, R.L., Nikolay, D., Jose, V.G., Christopher, S., Servane, D., Irene, A., ... \& Birgitta, W. (2008). Entrepreneurial intent: A twelve-country evaluation of Ajzen's model. International Journal of Entrepreneurial Behaviour \& Research, 16(1), 36-52.

Fillis, I. (2002). An Andalusian dog or a rising star? Creativity and the marketing/entrepreneurship interface. J. Mark. Manag. 18, 379-395. https://doi.org/10.1362/0267257022872415

Forouharfar, A., Rowshan, S.A., \& Salarzehi, H. (2018). An epistemological critique of social entrepreneurship definitions. J. Glob. Entrep. Res. 8(1), 11. https://doi.org/10.1186/s40497-018-0098-2

Fox J. (2002). Structural equation models Appendix to an R and S-PLUS Companion to Applied Regression. Retrieved from http://ftp.uni-bayreuth.de/math/statlib/R/CRAN/doc/contrib/FoxCompanion/ appendix-sems.pdf on April 30, 2020.

Germak, A.J., \& Robinson, J.A. (2014). Exploring the motivation of nascent social entrepreneurs. J. Soc. Entrep. 5(1), 5-21. https://doi.org/10.1080/19420676.2013.820781 
Gibb, A.A. (2002). Creating conducive environments for learning and entrepreneurship. Industry and Higher Education, 16(3), 135-47. https://doi.org/10.5367\%2F000000002101296234

Gómez-Carreto, T., Zarazúa Escobar, J.A., Guillen Cuevas, L.A., \& Castellanos Albores, A.C. (2018). Innovación social, turismo rural y empresas sociales. Evidencias desde el Sur-Sureste de México. El periplo sustentable, (34), 44-81.

Hair Jr, J.F., Hult, G.T.M., Ringle, C., Sarstedt, M., (2014). A primer on partial least squares structural equation modeling (PLS-SEM). 2e, California: Sage Publications.

Hair Jr, J. F., Sarstedt, M., Hopkins, L., \& Kuppelwieser, V. G. (2014). Partial least squares structural equation modeling (PLS-SEM). European business review, 26(2), 106-121. https://doi.org/10.1108/EBR-10-2013-0128

Hair Jr, J.F., Hult, G.T.M., Ringle, C., \& Sarstedt, M. (2016). A primer on partial least squares structural equation modeling (PLS-SEM). 2e, California, Sage pu engine?. Business Strategy Review, 15(4), 39-43. https://doi.org/10.1111/j.0955-6419.20blications

SHarding, R. (2004). Social enterprise: the new economic 04.00338.x

Henseler, J., Dijkstra, T.K., Sarstedt, M., Ringle, C.M., Diamantopoulos, A., Straub, D.W., ... \& Calantone, R.J. (2014). Common beliefs and reality about PLS: Comments on Rönkkö and Evermann 2013. Organizational Research Methods, 17(2), 182-209. https://doi.org/10.1177\%2F1094428114526928

Hills, G.E., Lumpkin, G.T., \& Singh, R.P. (1997). Opportunity recognition: Perceptions and behaviors of entrepreneurs. Frontiers of Entrepreneurship Research, 17, 168-182.

Hu, L.T., \& Bentler, P.M. (1998). Fit indices in covariance structure modeling: Sensitivity to underparameterized model misspecification. Psychological Methods, 3(4), 424. https://psycnet.apa.org/doi/10.1037/1082-989X.3.4.424

Hsu, D.K., Wiklund, J., \& Cotton, R.D. (2017). Success, failure, and entrepreneurial reentry: An experimental assessment of the veracity of self-efficacy and prospect theory. Entrepreneurship Theory and Practice, 41(1), 19-47. https://doi.org/10.1111\%2Fetap.12166

International Labor Organization (2020). Covid-19 and the word of work. Retrieved from https://www.ilo.org/global/about-the-ilo/WCMS_740877/lang--it/index.htm on April 20, 2020.

Jiménez-Jiménez, D., \& Sanz-Valle, R. (2011). Innovation, organizational learning, and performance. J. Bus. Res. 64, 408-417. https://doi.org/10.1016/j.jbusres.2010.09.010

Kazanjian, R.K. (1988). Relation of dominant problems to stages of growth in technology-based new ventures. Academy of Management Journal, 31(2), 257-279. https://doi.org/10.5465/256548

Kickul, J., Gundry, L., Mitra, P., \& Berçot, L. (2018). Designing with purpose: advocating innovation, impact, sustainability, and scale in social entrepreneurship education. Entrepreneurship Education and Pedagogy, 1(2), 205-221. https://doi.org/10.1177\%2F2515127418772177

Kirkley, W.W. (2016). Entrepreneurial behavior: the role of values. International Journal of Entrepreneurial Behavior \& Research, 22(3), 290-328. https://doi.org/10.1108/IJEBR-02-2015-0042

Kirzner, I.M. (2009). The alert and creative entrepreneur: A clarification. Small Business Economics, 32(2), 145-152. https://doi.org/10.1007/s11187-008-9153-7

Krueger Jr, N.F., Reilly, M.D., \& Carsrud, A.L. (2000). Competing models of entrepreneurial intentions. Journal of Business Venturing, 15, 411-432. https://doi.org/10.1016/S08839026(98)00033-0

Lumpkin, G.T., \& Dess, G.G. (1996). Clarifying the entrepreneurial orientation construct and linking it to performance. Academy of Management Review, 21(1), 135-172. https://doi.org/10.5465/amr.1996.9602161568 
Lumpkin, G.T., Moss, T.W., Gras, D.M., Kato, S., \& Amezcua, A.S. (2013). Entrepreneurial processes in social contexts: how are they different, if at all?. Small Bus. Econ., 40, 761-783. https://doi.org/10.1007/s11187-011-9399-3

Mauer, R., Neergaard, H., \& Linstad, A.K. (2017). Self-efficacy: Conditioning the entrepreneurial mindset. In Revisiting the entrepreneurial mind (pp. 293-317). New York: Springer. https://doi.org/10.1007/978-3-319-45544-0_19

Monllor, J., \& Attaran, S. (2008). Opportunity recognition of social entrepreneurs: an application of the creativity model. Int. J. Entrep. Small Bus., 6, 54-67. https://doi.org/10.1504/IJESB.2008.017389

Nicholls, A., \& Murdock, A. (2012). The nature of social innovation. In Social Innovation (pp. 1-30). New York: Springer.

Ng, T.W., \& Lucianetti, L. (2016). Within-individual increases in innovative behavior and creative, persuasion, and change self-efficacy over time: A social-cognitive theory perspective. Journal of Applied Psychology, 101(1), 14. https://psycnet.apa.org/doi/10.1037/apl0000029

Orth, M., \& Volmer, J. (2017). Daily within-person effects of job autonomy and work engagement on innovative behaviour: The cross-level moderating role of creative self-efficacy. European Journal of Work and Organizational Psychology, 26(4), 601-612. https://doi.org/10.1080/1359432X.2017.1332042

Perrini, F., \& Vurro, C. (2006). Social entrepreneurship: Innovation and social change across theory and practice. In Social Entrepreneurship (pp. 57-85). New York: Springer.

Perry-Smith, J.E., \& Mannucci, P.V. (2017). From creativity to innovation: The social network drivers of the four phases of the idea journey. Academy of Management Review, 42(1), 53-79. https://doi.org/10.5465/amr.2014.0462

Rao-Nicholson, R., Vorley, T., \& Khan, Z. (2017). Social innovation in emerging economies: A national systems of innovation based approach. Technological Forecasting and Social Change, 121, 228237. https://doi.org/10.1016/j.techfore.2017.03.013

Robichaud, Y., Cachon, J.C., Taghzouti, A., Assaidi, A., \& Codina, J.N.B. (2019). Entrepreneurial Motives in Two Emerging Economies: A Comparison between Urban Mexico and Morocco. Mediterranean Journal of Social Sciences, 10(1), 141.

Russell, D.W, Kahn, J.H, Spoth, R., \& Altmaier, E.M. (1998). Analyzing data from experimental studies: A latent variable structural equation modeling approach. Journal of Counseling Psychology 45(1), 18. https://psycnet.apa.org/doi/10.1037/0022-0167.45.1.18

Sandoval, H. (2019). Barriers to hybrid social entrepreneurship in Mexico. Projectics/Proyectica/Projectique, (2), 43-61.

Santos, F.M. (2012). A positive theory of social entrepreneurship. Journal of Business Ethics, 111(3), 335-351. https://doi.org/10.1007/s10551-012-1413-4

Sarstedt, M., Ringle, C.M., Smith, D., Reams, R., \& Hair Jr, J.F. (2014). Partial least squares structural equation modeling (PLS-SEM): A useful tool for family business researchers. Journal of Family Business Strategy, 5(1), 105-115. https://doi.org/10.1016/j.jfbs.2014.01.002

Scillitoe, J.L., Poonamallee, L., \& Joy, S. (2018). Balancing market versus social strategic orientations in socio-tech ventures as part of the technology innovation adoption process-examples from the global healthcare sector. Journal of Social Entrepreneurship, 9(3), 257-287. https://doi.org/10.1080/19420676.2018.1498378

Sen, P. (2007). Ashoka's big idea: Transforming the world through social entrepreneurship. Futures, 39, 534-553. https://doi.org/10.1016/j.futures.2006.10.013 
Shepherd, D.A., Patzelt, H., \& Baron, R.A. (2013). "I care about nature, but...": Disengaging values in assessing opportunities that cause harm. Academy of Management Journal, 56(5), 1251-1273. https://doi.org/10.5465/amj.2011.0776

Shir, N., Nikolaev, B.N., \& Wincent, J. (2019). Entrepreneurship and well-being: The role of psychological autonomy, competence, and relatedness. Journal of Business Venturing, 34(5), 105875. https://doi.org/10.1016/j.jbusvent.2018.05.002

Smith, R., Bell, R., \& Watts, H. (2014). Personality trait differences between traditional and social entrepreneurs. Social Enterprise Journal. 10(3), 200-221. https://doi.org/10.1108/SEJ-08-2013-0033

Tang, J. (2008). Environmental munificence for entrepreneurs: entrepreneurial alertness and commitment. International Journal of Entrepreneurial Behaviour and Research, 14(3), 128-151. https://doi.org/10.1108/13552550810874664

Valencia-Arias, J.A., \& Marulanda-Valencia, F.Á. (2019). Evolution and research trends in entrepreneurial self-efficacy: a bibliometric análisis. Estudios Gerenciales, 35(151), 219-232. https://doi.org/10.18046/-j.estger.2019.151.3277

Van Gelderen, M. (2010). Autonomy as the guiding aim of entrepreneurship education. Education+ Training. 52(8/9), 710-721. https://doi.org/10.1108/00400911011089006

Vargas-Chanes, D. (2019). Aspectos metodológicos para la investigación social: Modelos de ecuaciones estructurales. México: UNAM.

Vega, G., \& Kidwell, R.E. (2007). Toward a typology of new venture creators: similarities and contrasts between business and social entrepreneurs. N. Engl. J. Entrep., 10(4), https://digitalcommons.sacredheart.edu/neje/vol10/iss2/4

Villanueva, J.L.J., Jimenez, J.M., Garrido, J.S.E., \& Castro, J.G.R. (2012). Perfil emprendedor de los pequeños empresarios agropec uarios en el Valle de Puebla, México. Entramado, 8(1), 44-57.

Villegas-Mateos, A., \& Vázquez-Maguirre, M. (2020). Social entrepreneurial ecosystems: a regional perspective of Mexico. International Journal of Entrepreneurship, 24(1), 1-19.

Vuong, Q.H., \& Napier, N.K. (2014). Making creativity: the value of multiple filters in the innovation process. International Journal of Transitions and Innovation Systems, 3(4), 294-327. https://doi.org/10.1504/IJTIS.2014.068306

Ward, T.B. (2004). Cognition, creativity, and entrepreneurship. J. Bus. Ventur. 19, 173-188. https://doi.org/10.1016/\$0883-9026(03)00005-3

Westley, F., \& Antadze, N. (2010). Making a difference: Strategies for scaling social innovation for greater impact. The Innovation Journal: The Public Sector Innovation Journal, 15(2), 1-19.

Witkamp, M.J., Raven, R.P., \& Royakkers, L.M. (2011). Strategic niche management of social innovations: the case of social entrepreneurship. Technology Analysis \& Strategic Management, 23(6), 667-681. https://doi.org/10.1080/09537325.2011.585035

Wong, K.K.-K. (2013). Partial least squares structural equation modeling (PLS-SEM) techniques using SmartPLS. Mark. Bull., 24, 1-32.

Wulleman, M., \& Hudon, M. (2016). Models of social entrepreneurship: empirical evidence from Mexico. J. Soc. Entrep. 7, 162-188. https://doi.org/10.1080/19420676.2015.1057207

Yang, M.L., Wang, A.M.L., \& Cheng, K.C. (2009). The impact of quality of IS information and budget slack on innovation performance. Technovation, 29(8), 527-536. https://doi.org/10.1016/j.technovation.2009.01.004

Yujuico, E. (2008). Connecting the dots in social entrepreneurship through the capabilities approach. Socio-economic Review, 6(3), 493-513. https://doi.org/10.1093/ser/mwn003 
Zahra, S.A., Gedajlovic, E., Neubaum, D.O., \& Shulman, J.M. (2009). A typology of social entrepreneurs: Motives, search processes and ethical challenges. Journal of Business Venturing, 24(5), 519-532. https://doi.org/10.1016/j.jbusvent.2008.04.007

\section{Authors}

The contribution of co-authors is as follows: María Teresa de la Garza Carranza (50\%) prepared the manuscript and the statistical analysis. Jorge Armando López-Lemus (20\%) and Eugenio Guzmán-Soria (25\%) reviewed the statistical part and contributed to formulating the conclusions of the paper. Ana Cristina Sierra Martínez (5\%) collected the data.

\section{María Teresa de la Garza Carranza}

Doctor in Management Science (Instituto Politécnico Nacional, México). Professor at the Tecnológico Nacional de México in Celaya. Her research interests are small business, cross-cultural management, and organization behaviour.

Correspondence to: Dra. María Teresa de la Garza Carranza, Tecnológico Nacional de México en Celaya. Av. Tecnológico SN Celaya Gto, 38060. Department of Economic and Business Sciences, e-mail: teresa.garza@itcelaya.edu.mx

ORCID (1) http://orcid.org/0000-0002-4877-3403

\section{Eugenio Guzmán-Soria}

Doctor in Economy (Colegio de Posgraduados, México). Professor at the Tecnológico Nacional de México in Celaya. His research interests are macroeconomics and microeconomics.

ORCID (1) http://orcid.org/0000-0003-4713-7154

\section{Jorge Armando López-Lemus}

Doctor in Management and Organizational Studies (Universidad de la Salle Bajío, México). Professor at the Universidad de Guanajuato, Campus Irapuato-Salamanca. His research interests are small business and organizational behaviour.

ORCID (1) http://orcid.org/0000-0001-6989-1065

\section{Ana Cristina Sierra-Martínez}

Master's in Management (Tecnológico Nacional de México en Celaya, México). Assistant Professor at the Tecnológico Nacional de México in Roque. Her research interest is small business.

\section{Copyright and License}

This article is published under the terms of the Creative Commons

Attribution - NoDerivs (CC BY-ND 4.0) License

http://creativecommons.org/licenses/by-nd/4.0/

Published by Cracow University of Economics - Krakow, Poland 